\title{
Effects of environmental factors on Tigriopus fulvus, Fischer 1860, a Mediterranean harpacticoid copepod
}

\author{
Guido Bonello, Cristiano Angelini, Luigi Pane \\ Department of Earth, Environment and Life Sciences, University of Genoa, Genoa, Italy
}

\begin{abstract}
Tigriopus fulvus (Fischer, 1860) is a benthic harpacticoid copepod of the Mediterranean supralittoral zone. The transitional characteristics of this environment forced this species to develop high resistance to changes of environmental parameters. Nevertheless, T. fulvus life-cycle is influenced from the splashpools physical-chemical parameters. In this paper, we present the results of a supralittoral monitoring performed in 2014, confirming the influence of some of these environmental parameters on population buildups. Because of recent worldwide climate change effects, a threat might have been posed on this particularly exposed organism, whose population density decreased of a sixfold value in the last 30 years. During the three pools (A, B, C) monitoring, the maximum copepod density recorded was 1456 Ind/1 (September 2014, Pool C), alongside first records of extinction event for T. fulvus.
\end{abstract}

\section{Introduction}

The marine rocky littoral system is divided into well-defined

Correspondence: Guido Bonello, Department of Earth, Environment and Life Sciences, University of Genoa, Viale Benedetto XV 5,

16132, Genoa, Italy.

E-mail: bonello.guido@gmail.com

Key words: Copepod; Metapopulations; Climate change; Tigriopus fulvus.

Contributions: the authors contributed equally.

Conflict of interest: the authors declare no potential conflict of interest.

Funding: none.

Received for publication: 1 October 2017.

Revision received: 28 December 2017.

Accepted for publication: 29 December 2017.

CCopyright G. Bonello et al., 2018

Licensee PAGEPress, Italy

Journal of Biological Research 2018; $91: 7113$

doi:10.4081/jbr.2018.7113

This article is distributed under the terms of the Creative Commons Attribution Noncommercial License (by-nc 4.0) which permits any noncommercial use, distribution, and reproduction in any medium, provided the original author(s) and source are credited. $\operatorname{areas}^{1,2}$ and represents a transitional environment between land and sea. Here, environmental conditions show sudden and critical variations to which resident organisms need to react with refined adaptation and tolerance techniques. ${ }^{3}$ These collections of temporary water represent, particularly in the supralittoral zone, an ubiquitously distributed environment. Because of low tidal activity, in Mediterranean splashpools most of water inputs come from sea storms and rainfall. ${ }^{4}$ Many aspects of the ecology of this habitat were studied and described during the last decades. ${ }^{5-15}$ The benthic harpacticoid copepod Tigriopus sp. is known to be one of the most representative and adapted species in the supralittoral environment. The genus Tigriopus includes many different species, with worldwide distribution ranging from North-American coasts ${ }^{16}$ to Antarctica. ${ }^{17}$ Two European species are described, but Tigriopus fulvus is the only one living along the Mediterranean coasts. ${ }^{18} \mathrm{~T}$. fulvus is also known to be an useful test species in ecotoxicology, whose reliability was tested with different matrices and pollutants. ${ }^{19-27}$ This species inhabits splashpools or rockpools, and therefore it is exposed to a wide variety of environmental conditions that promoted refined adaptation and resistance characteristics. Such variability is ascribed to cycles of drying out or inundation of rockpools, depending on rainfall, waves exposition and sunlight. This paper resumes a seasonal study on splashpools and a comparison with historical T. fulvus population data, in order to explore the health-state of copepod population.

\section{Materials and Methods}

\section{Study area}

The studied T. fulvus population can be currently found in Genova Nervi splashpools (Ligurian Sea, 44²2'52.561 N; $9^{\circ} 2^{\prime} 12.570 \mathrm{E}$ ). Three different splashpools (A, B, C) having different structural characteristics were chosen at different height and distance from the sea (Figure 1). Studied pools are classified as splashpools, defined as located above the high-tide line and receiving marine water inputs only by sprays during heavy seas and storms and not located in the intertidal zone. ${ }^{2}$

Splashpools number was considered sufficient as the coastal morphology of the study sites concentrates many pools in relatively narrow space. Pools with the same sunlight exposition were chosen, this means that no structural coverage might cause differences in pool water warming. Mean pool surface and mean depth were about $2 \mathrm{~m}^{2}$ and $0.5 \mathrm{~m}$, respectively. Height from the sea level ranged between 4 and 6 meters (A to C). The splashpools were chosen taking into account the occurrence of T. fulvus at the beginning of samplings. Samplings followed a fortnightly check, from March to September 2014. 


\section{Environmental and atmospheric parameters}

Splashpools temperature and salinity were acquired through a multiparametric probe (YSI $30 \mathrm{M} / 50 \mathrm{FT} ; 0.1^{\circ} \mathrm{C}$ and 0.1 resolution), a different probe was needed for $\mathrm{pH}$ measures (Etekcity 009, 0.1 resolution, 0.1 accuracy at $20^{\circ} \mathrm{C}$ ). Chlorophyll a and Total Particulate Matter (TPM) analysis were performed on water samples collected with opaque plastic bottles. Chlorophyll a $\left(\mathrm{Chl}_{\mathrm{a}}\right)$ analysis was performed following a spectrophotometric method (Analytic Jena Spekol 1300). Water samples were filtered on glass-microfibre filters (GF/A Whatman), and subsequently exposed to an overnight acetone:distilled water $(90: 10 \quad \mathrm{v}: \mathrm{v})$ extraction prior to spectrophotometric analysis. ${ }^{28}$ To evaluate TPM, water samples were filtered on $0.45 \mu \mathrm{m}$ porosity Sartorius cellulose acetate filters. Ponderal analysis was performed on analytic scale, after 2 hours filters oven-drying $\left(130^{\circ} \mathrm{C}\right)$ followed by 1.5 hours in silica-gel dryer. Organic percentage composition of TPM was evaluated with ash weighing after a $2 \mathrm{~h} / 550^{\circ} \mathrm{C}$ burning in muffle furnace. Rainfall data were obtained from the Liguria Region Weather Hydrological Observatory, a data collection web composed of almost 230 measuring stations spread across Liguria Region.

\section{Sampling of specimens}

A plastic $250 \mathrm{~mL}$ bottle was used to collect samples that were subsequently fixed in $70 \%$ ethanol (v:v); sampling bottle was dragged along the top of the south facing pool wall, every sampling day at noon, as made in previous fieldwork. ${ }^{12}$ T. fulvus specimens were collected to follow the population variability in terms of density and composition. Copepods counting was carried out under light microscope (Nikon SM7-U); Five categories were assigned to determine population structure, males, females, ovigerous females, copepodites (C1-C5) and nauplii (N1-N6). Ovigerous females frequency was considered as an indicator for reproductive events constancy, and to evaluate a possible source and sink dynamic between the studied splashpools as well. Copepodite stages were recognized by size and morphology, while nauplii were identified from body shape and a maximum of four thoracic segments.

\section{Statistical analysis}

Spearman rank correlation analysis were performed by the mean of StatSoft STATISTICA 10 software. Boxplot presence/absence analysis was performed in the $\mathrm{R}$ environment.

\section{Results}

\section{Environmental parameters}

Spatial and temporal variability of the supralittoral environment was highlighted during the samplings; temperature and salinity data are displayed in a T-S graph (Figure 2). Pool C showed wide mean variability of environmental parameters, with peaks in salinity (55.8 $\pm 24.2 \%$ ) , density (1035 \pm 15.6$)$ and $\mathrm{pH}(8.4 \pm 0.5)$. Pool A, showed wider oscillations during the sampling period $\left(24.8 \pm 8.8^{\circ} \mathrm{C}\right)$. The highest salinity value was reached in pool C with $90 \%$ (July 2014). Pool C also showed the lowest $\mathrm{pH}$ value ( $\mathrm{pH}=7.3$, July 2014).

TPM and chlorophyll resulted higher in pool $\mathrm{C}$, where trophic conditions seem to be more favorable for T. fulvus population, in terms of quantity (mean $193 \mathrm{mg} / \mathrm{L} \mathrm{TPM}$ ) and quality (mean organic particulate composition of 58.6\%) than in Pool A (49.15 mg/L and $39.6 \%$ ). Pool A population (Figure $3 \mathrm{~A}$ ) reached a top value of 424 individuals per liter (Ind/1) in April 2014, but it was nevertheless recognized as the most scarcely populated pool, with a mean population density of $155.6 \mathrm{Ind} / 1$. Pool B and Pool C showed higher mean population densities ( $285 \mathrm{ind} / 1$ and $448,9 \mathrm{ind} / 1$, respectively), but different population behaviors. Pool B population (Figure 3B) reached a maximum of $1428 \mathrm{Ind} / 1$ (September 2014) and did not show extinction events. Pool C (Figure 3C) reached the population peak in September 2014 as well (1456 Ind/1), and the minimum in August 2014 (136 Ind/l). Pool C went into extinction in the first two weeks of July 2014.

Pool B showed significant reproductive events, where ovigerous females almost reached the $50 \%$ of the total population (Figure 4); pool A showed the highest (24.2\%) mean value for this parameter. Regarding Pool A population, the occurrence of ovigerous females (Figure 4) was reported during all the examined period, nevertheless the scarce mean density does not allow to highlight reproduction events. Mean Spearman Rank analysis between population and ovigerous females density highlights a high correlation (mean $\left.\mathrm{r}_{\mathrm{s}}=0.77, \mathrm{P}<0.05\right)$.

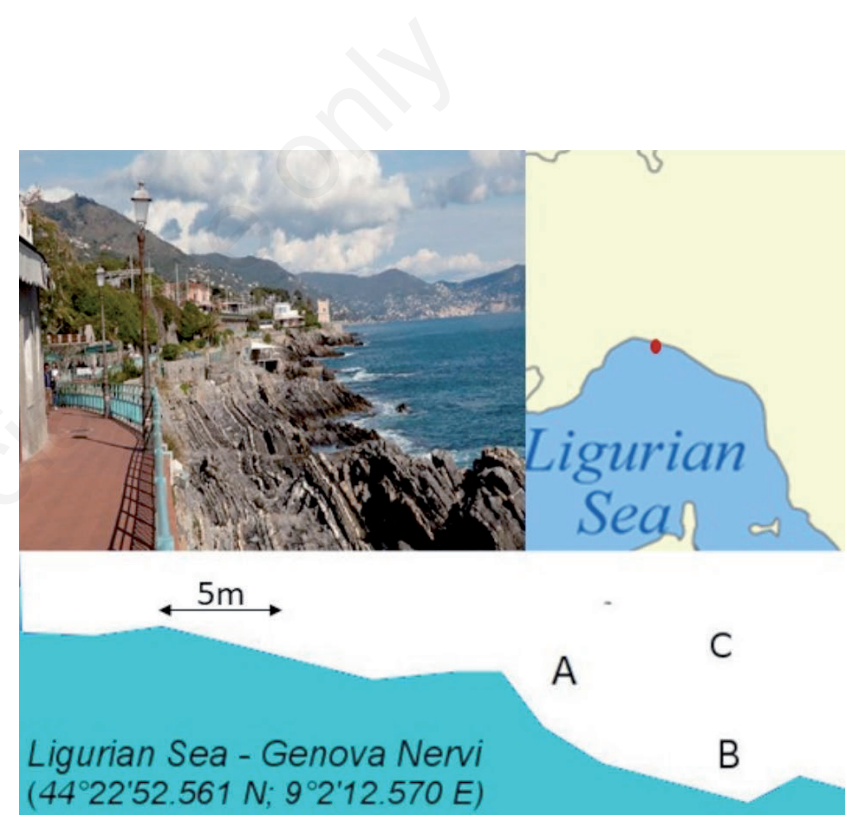

Figure 1. Study area map and splashpools distribution.

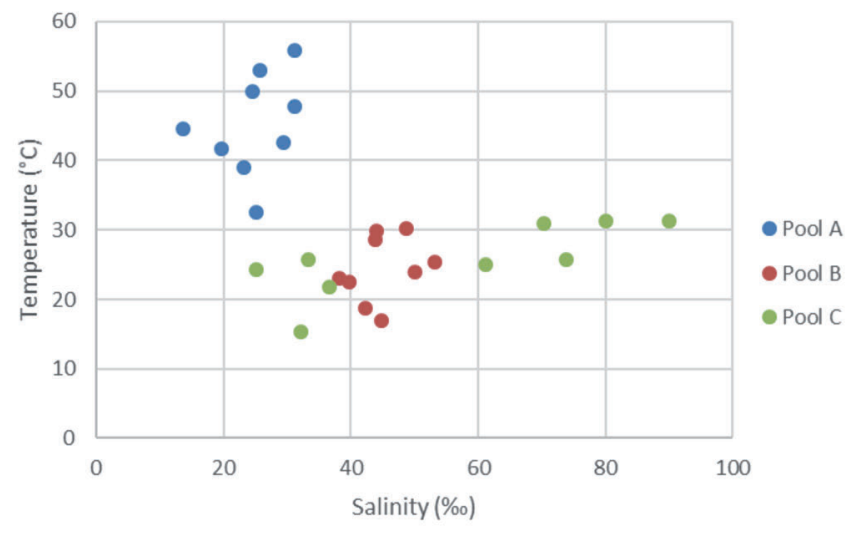

Figure 2. Temperature and salinity distribution in Pool A, B and C (March-October 2014). 


\section{Discussion}

Meteorological parameters influence the supralittoral environment, determining a wide variability of salinity, temperature and general pools condition. Splashpools populations are influenced by such parameters and by phytoplankton biomass availability. Studies on Tigriopus brevicornis showed that this organism has a wide tolerance toward environmental parameters variability, that nevertheless affect copepod survival and development. ${ }^{29,30}$ It was suggested that a considerable energetic cost is paid by the supralittoral inhabitants to survive and fight environmental changes. ${ }^{31}$ Tigriopus japonicus can survive at $1.8 \%$ water salinity, but the most suitable range for reproduction is between 27.1 and $34.3 \%$. $^{32,33}$ The wide variability of environmental parameters may overcome Tigriopus sp. survival mechanisms, such as osmotic, temperature and desiccation tolerance, as it was observed in Tigriopus californicus. ${ }^{34-36}$ On this latter species, a limit of adaptation to raising temperatures was found, putting this welladapted organism under the climate change threat. ${ }^{16}$

The T. fulvus population in Genova Nervi (Ligurian Sea) showed genus-typical adaptability to environmental variability. Concerning the splashpools trophic conditions, $\mathrm{Chl}_{\mathrm{a}}$ and TPM peaks during April $2014\left(\mathrm{Chl}_{\mathrm{a}=} 98.32 \mathrm{mg} / \mathrm{L}\right.$; TPM=68.52 mg/L) and September $2014\left(\mathrm{Chl}_{\mathrm{a}}=98.32 \mathrm{mg} / \mathrm{L}\right.$; TPM=607.1 mg/L) matched with T. fulvus population buildups; on the other hand, Pool C went through a drying event which caused extinction of T. fulvus population in July 2014. In comparison with data from 1987, ${ }^{12}$ the results of this study show a decrease in mean T. fulvus population. While older samplings highlighted a mean copepod density of

A

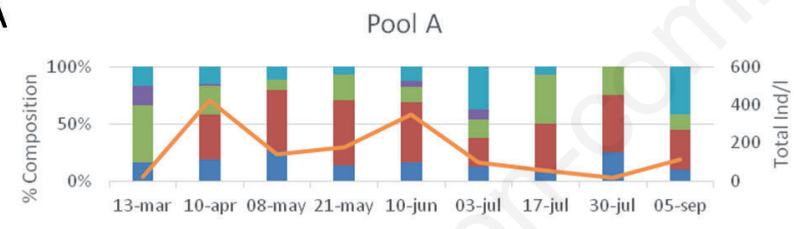

Males Females Ovigerous Nauplii $=$ Copepodites $\longrightarrow$ Ind/

B

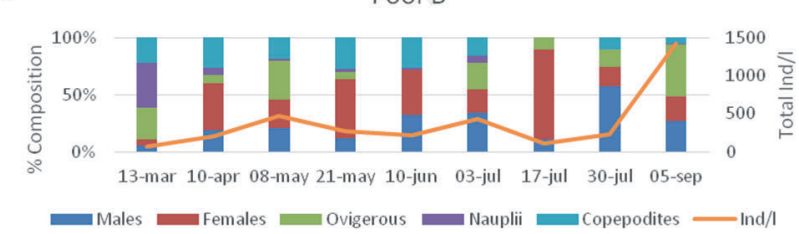

C

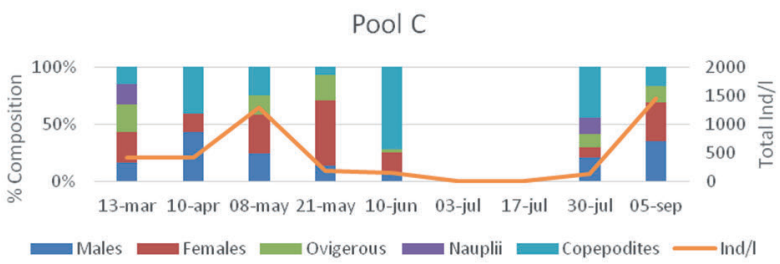

Figure 3. Percent composition of Tigriopus fulvus population categories in A) pool A, B) pool B and C) pool C coupled with total individual density (Ind/I) in the sample (March-October 2014).
$2699 \pm 1058$ Ind/L from March to September 1987, the data from 2014 showed a density of $580 \pm 630 \mathrm{Ind} / \mathrm{L}$; therefore, a fivefold mean population density decrease occurred. The comparison between the data of environmental parameters highlights a remarkable temperature rise $\left(\right.$ mean $=25.9^{\circ} \mathrm{C}$, range $\left.=21.8-31.36^{\circ} \mathrm{C}\right)$ with respect to the previous data from the same rockpool (mean $=22.1^{\circ} \mathrm{C}$, range $=16.5-27.0^{\circ} \mathrm{C}$ ). Similar considerations can be made regarding water temperature and density. ${ }^{12}$

\section{Conclusions}

Even though two points do not constitute a trend, especially in a highly variable species, the first signs of a reached tolerance limit must be considered, because of the assessed growth rate decrease. ${ }^{37}$ As already assessed, ${ }^{12}$ thermal tolerance is a crucial factor in Tigriopus spp. survival in the natural environment. Despite genetic adaptation and phenotypic plasticity that might buffer the adverse effects of the environmental temperature increase, the response that T. fulvus shows to climate change effects might not be sufficient to overcome the subsequent stress.

All in all, T. fulvus presence in the three studied rockpools is determined by a combination of the mentioned environmental factors, as shown in the subsequent presence/absence analysis. Primarily, as expected, splashpools water salinity affects $T$. fulvus fitness and therefore its presence in the studied pools (Figure 5); absence data of water temperature and salinity refer to small water remainings that can be found under the bottom salt crust, no copepods were present. A further environmental temperature increase might affect the fitness of supralittoral organisms up to their tolerance limit. Moreover, environmental temperature is correlated with pool water evaporation and subsequent salinity increase, that might lead to further distress for the resident populations (Figure 5).

Metapopulation structure has been already highlighted for $T$. fulvus. ${ }^{15}$ If for T. brevicornis ${ }^{38}$ and T. californicus $^{39}$ the individual distribution and the subsequent splashpools colonization seem to be affected by tidal activity, for T. fulvus this phenomenon is more connected to sea storms and rainfall. The correlation between populations $\mathrm{B}(\mathrm{r}=0.81, \mathrm{P}<0.05)$ and $\mathrm{C}(\mathrm{r}=0.75, \mathrm{P}<0.05)$ and cumulate rainfall between samplings (Figure 6) highlighted between March and September 2014 (Figure 3), could confirm this

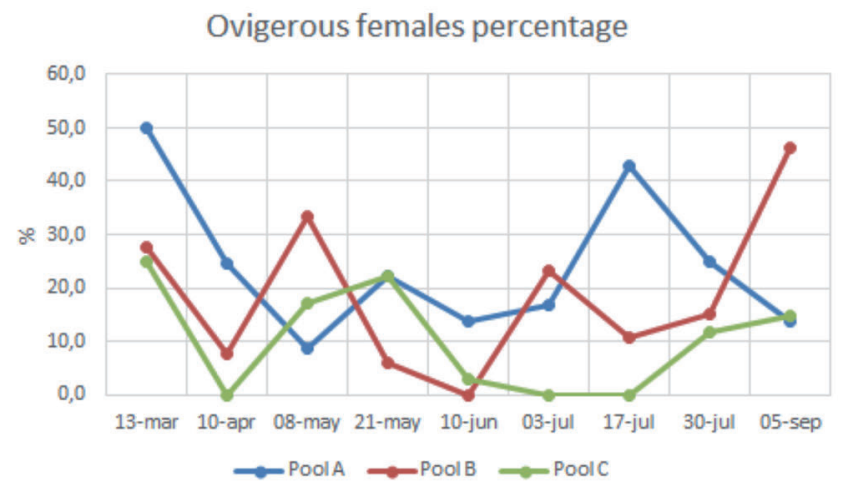

Figure 4. Ovigerous females percentage in Tigriopus fulvus populations of pools $\mathrm{A}, \mathrm{B}$ and $\mathrm{C}$. 
hypothesis. Pool A lower population densities did not allow a significant statistical data treatment.

The opportunistic behavior as r-specialist showed in this study by the harpacticoid copepod T. fulvus seems to be triggered and sustained by rainfall. T. fulvus survival during warmer months seems to rely on several factors, as for this species lethal temperature and salinity seem to be, moreover, directly correlated. ${ }^{40}$ In a context of climatic changes, wild populations of extreme environments such as splashpool copepods might be carefully monitored to locate possible local climate change effects.
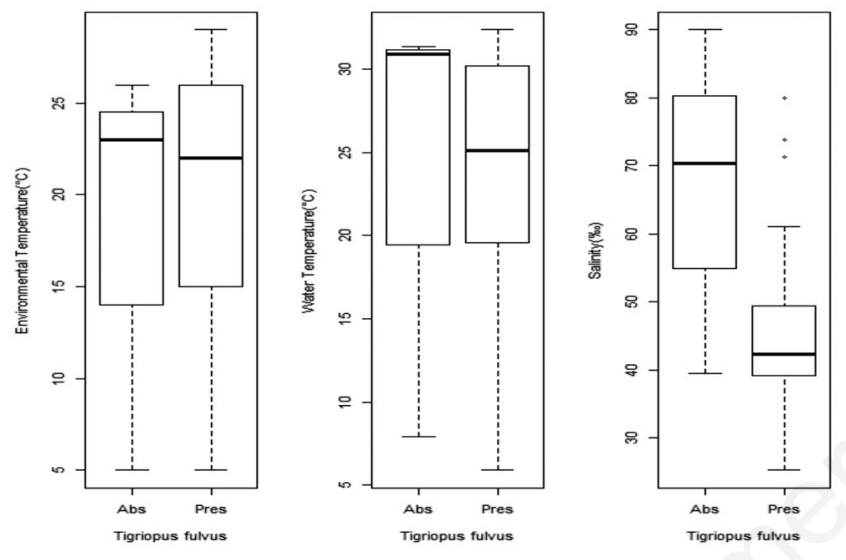

Figure 5. Presence/Absence of Tigriopus fulvus in the study area and environmental factors of pools A, B and C.

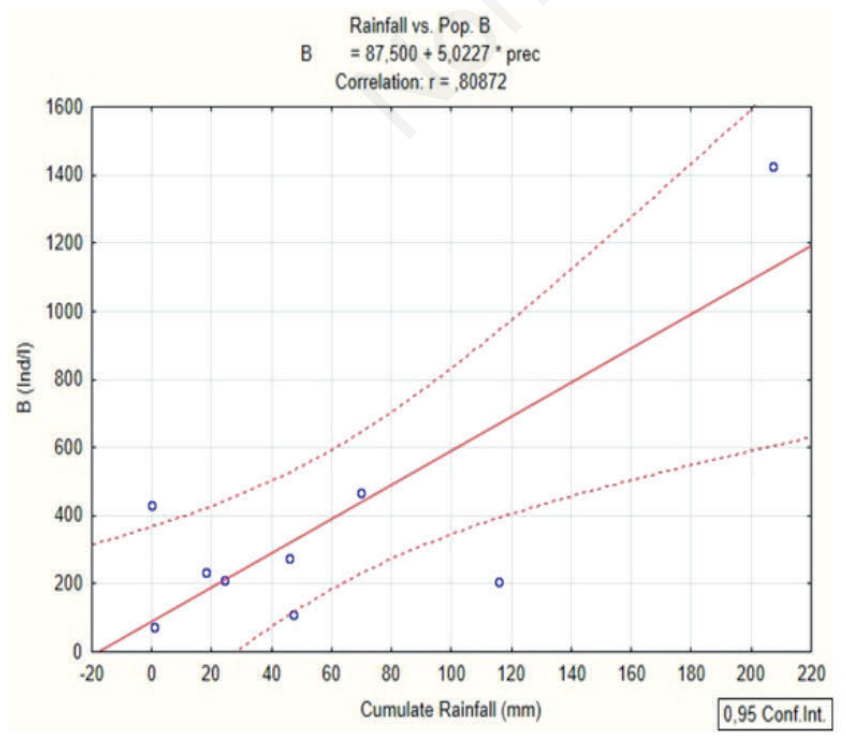

\section{References}

1. Stephenson TA. The universal features of zonation on rocky shores. J Ecol 1949;37:289-305.

2. Metaxas A, Scheibling RE. Community structure and organization of tidepools. Mar Ecol Prog Ser 1993;98:187-98.

3. Nybakken JW. Marine biology. An ecological approach. 4th edition. Menlo Park, CA; 1997.

4. Pane L, Mariottini GL. Characteristics of the rocky littoral system: biological and ecological aspects. In: Macias B, Guajardo F, eds. Rock Chemistry. Hauppauge, NY: NOVA Science Publ; 2010. pp 121-131.

5. Issel R. Vita latente per concentrazione dell'acqua (anabiosi osmotica) e biologia delle pozze di scogliera. Mittheil Zool Stat Zu Neapel 1914;22:191-225.

6. Issel R. Biologia marina, forme e fenomeni della vita nel mare. Milano, Hoepli; 1918.

7. Pérès JM, Picard J. Nouveau manuel de bionomie benthique de la Mer Mediterranée. Recueil Travaux Station Marine d'Endoume 1964;31:5-137.

8. Carli A. Reperti di Aedes mariae nelle pozze di scogliera dei dintorni di Genova e a S. Maria di Leuca. Natura 1967;58: 208-20.

9. Truchot JP, Duhamel-Jouve A. Oxygen and carbon dioxide in the marine intertidal environment: Diurnal and tidal changes in rockpools. Resp Physiol 1979;39:241-54.

10. Ghirardelli E. Il nostro universo. La vita nelle acque. Torino: UTET; 1981.

11. Morris S, Taylor AC. Diurnal and seasonal variation in physicochemical conditions within intertidal rockpools. Estuar Coast Shelf Sci 1982;17:339-55.

12. Pane L, Feletti M, Carli AM. Fattori ambientali e fluttuazioni della popolazione del copepode Tigriopus fulvus delle pozze di scogliera di Genova-Nervi (Mar Ligure). S.It.E. Atti 1996; 17:317-20.

13. Pane L, Capelli R, Paganelli L, Carli AM. Inorganic mercury in

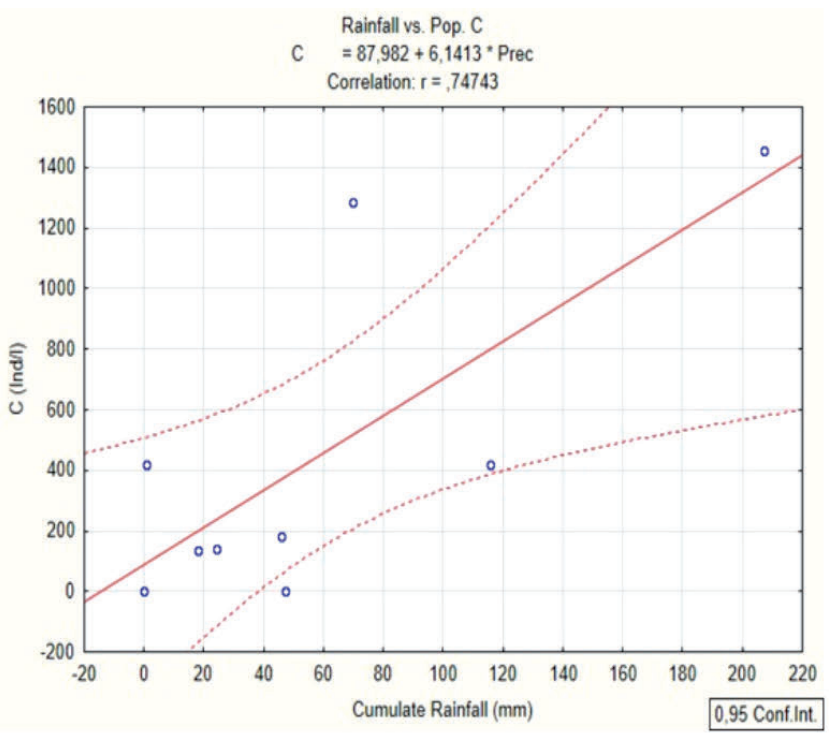

Figure 6. Spearman rank correlation between cumulate rainfall and Tigriopus fulvus populations (March-October 2014). 
the rock pool environment (Ligurian Sea). J Biol Res - Boll Soc It Biol Sper 2001;77:7-12.

14. Romanuk T, Kolasa J. Resource limitation, biodiversity and competitive effects interact to determine the invasibility of rockpools microcosms. Biol Invasions 2003;7:711-22.

15. Bonello G, Pane L. Metapopulation structure of a benthic harpacticoid copepod and environmental factors. Rapp. Comm Int Mer Médit 2016;41:346.

16. Kelly MW, Sanford E, Grosberg RK. Limited potential for adaptation to climate change in a broadly distributed marine crustacean. Proc Royal Soc 2012;279:349-56.

17. Park E-O, Lee S, Cho M, et al. A new species of the genus Tigriopus (Copepoda: Harpacticoida: Harpacticidae) from Antarctica. Proc R Soc Wash 2014;127:138-54.

18. Carli A, Fiori A. Morphological analysis of the two Tigriopus species found along the European coasts. Natura 1977;68: 101-10.

19. Faraponova O, De Pascale D, Onorati F, Finoia MG. Tigriopus fulvus (Copepoda, Harpacticoida) as a target species in biological assays. Meiofauna Marina 2005;14:91-5.

20. Pane L, Giacco E, Mariottini GL. Utilizzo di Tigriopus fulvus (Copepoda: Harpacticoida) in ecotossicologia. Saggi con disperdenti e tensioattivi. Biol Mar Medit 2006;13:348-9.

21. Pane L, Giacco E, Mariottini GL. Uso di Tigriopus fulvus (Copepoda: Harpacticoida) nella valutazione del rischio ecotossicologico in ambiente marino. Biol Mar Medit 2007; 14:186-8.

22. Pane L, Mariottini GL, Lodi A, Giacco E. Effects of heavy metals on laboratory reared Tigriopus fulvus Fischer (Copepoda: Harpacticoida). In: Brown SE, Welton WC, eds. Heavy Metal Pollution. Hauppauge, NY: NOVA Science Publ 2008;6:157-65.

23. Pane L, Giacco E, Corrà C, et al. Ecotoxicological evaluation of harbour sediments using marine organisms from different trophic levels. J Soils Sedim 2008;8:74-9.

24. Pane L, Agrone C, Giacco E, et al. Utilization of marine crustaceans as study models: a new approach in marine ecotoxicology for European (REACH) regulation. In: Begum G, ed. Ecotoxicology. Rijeka: InTech; 2012.

25. Pane L, Mariottini GL, Giacco E. Ecotoxicological assessment of the micelle encapsulator F-500. Ecotox Environ Safe 2015;118:167-76.

26. Faraponova O, Giacco E, Biandolino F, et al. Tigriopus fulvus: The interlaboratory comparison of the acute toxicity test. Ecotox Environ Safe 2016;124:309-14.

27. Biandolino F, Parlapiano I, Faraponova O, Prato E. Effects of short- and long-term exposures to copper on lethal and reproductive endpoints of the harpacticoid copepod Tigriopus fulvus. Ecotox Environ Safe 2018;147:327-33.

28. Strickland JDH, Parsons TR. A practical handbook of seawater analysis. Fish Res Bd Canada 1972;167.

29. McAllen R, Taylor AC, Davenport J. The effects of temperature and oxygen partial pressure on the rate of oxygen consumption of the high-shore rock pool copepod Tigriopus brevicornis. Comp Biochem Physiol A 1999;123:195-202.

30. McAllen R, Taylor A. The effect of salinity change on the oxygen consumption and swimming activity of the high-shore rockpool copepod Tigriopus brevicornis. J Exp Mar Biol Ecol 2001;263:227-40.

31. McAllen R, Brennan E. The effect of environmental variation on the reproductive development time and output of the highshore rockpool copepod Tigriopus brevicornis. J Exp Mar Biol Ecol 2009;368:75-80.

32. Lee C-S, Hu F. Salinity tolerance and salinity effects on brood size of Tigriopus japonicus Mori. Aquaculture 1981;22:377-81.

33. Hagiwara A, Lee C-S, Shiraishi DJ. Some reproductive characteristics of the broods of the harpacticoid copepod Tigriopus japonicus cultured in different salinities. Fish Sci 1995;61:618-22.

34. Egloff DA. Ecological aspects of sex ratio and reproduction in experimental and field populations of the marine copepod Tigriopus californicus. PhD thesis. Stanford, CA, USA: Stanford University Press; 1967.

35. Vittor BA. Effects of the environment on fitness-related life history characters in Tigriopus californicus. $\mathrm{PhD}$ thesis. Eugene: University of Oregon Press; 1971.

36. Burton RS, Feldman MW, Curtsinger JW. Population genetics of Tigropius californicus (Copepoda: Harpacticoida): I. Population structure along the central California coast. Mar Ecol Prog Ser 1979;1:29-39.

37. Schreiber SJ. Interactive effects of temporal correlations, spatial heterogeneity and dispersal on population persistence. Proc Biol Sci 2010;277:1907-14.

38. Johnson MP. Metapopulation dynamics of Tigriopus brevicornis (Harpacticoida) in intertidal rock pools. Mar Ecol Prog Ser 2001;211:215-24.

39. Altermatt F, Bieger A, Morgan SG. Habitat characteristics and metapopulation dynamics of the copepod Tigriopus californicus. Mar Ecol Prog Ser 2012;468:85-93.

40. Ranade MR. Observations on the resistance of Tigriopus fulvus (FISCHER) to changes in temperature and salinity. J Mar Biol Assoc UK 1957;36:115-9. 